\title{
STUDI FENOMENOLOGI : KESADARAN DIRI ( SELF AWARENESS) PEROKOK AKTIF YANG MEMPUNYAI ANAK BALITA DALAM PERILAKU MEROKOK DI TEMPAT UMUM DI KELURAHAN PEGULON, KABUPATEN KENDAL
}

\author{
Shinta Ika Sandhi ${ }^{1}$ \\ Email : shinta86harnuddin82@gmail.com \\ Stikes Uniska Kendal \\ Jl.Soekarno Hatta No 99 Kendal \\ Telp/Fax (0294) 381299
}

\begin{abstract}
Abstrak
Beberapa tahun belakangan bahaya tentang asap rokok tidak hanya difokuskan kepada perokok aktif saja namun juga dampak yang diterima oleh perokok pasif. Semakin meningkatnya masalah yang diterima oleh perokok pasif baik di rumah maupun di lingkungan tempat kerja memungkinkan terjadinya dampak yang ditimbulkan oleh asap rokok. Hal tersebut menunjukkan terdapatnya bahaya ganda yang ditimbulkan oleh asap rokok yang tidak hanya diterima oleh perokok aktif namun juga oleh orang di sekitarnya (Bustan, 2000). Di Kabupaten Kendal prosentase perokok di dominasi oleh pria, dimana hampir 85\% menjadi perokok aktif. Salah satu dampak rokok bagi perokok pasif antara lain terkena penyakit infeksi saluran pernapasan atas (ISPA). Berdasarkan laporan SP3 Puskesmas di Kabupaten Kendal menunjukan bahwa kasus ISPA masih menajdi kasus paling banyak di Kabupaten Kendal sebesar 140.305 penderita. Jenis penelitian ini adalah kualitatif dengan menggunakan wawancara mendalam. Informan utama dalam penelitian ini adalah pria perokok aktif yang mempunyai anak balita sebanya 5 orang. Teknik analisa data dengan analisa konten, meliputi wawancara mendalam dengan informan diolah kemudian dilakukan analisis data. Hasil penelitian menunjukkan bahwa informan utama sudah mengerti tentang bahaya asap rokok bagi perokok aktif, namun tidak memahami tentang bahaya merokok bagi perokok pasif sehingga kesadaran untuk merokok di tempat yang jauh dari jangkauan anak balita belum ada.
\end{abstract}

Kata Kunci : Rokok, perokok aktif, perokok pasif, dampak rokok.

\section{Pendahuluan}

Merokok sudah dikenal masyarakat sebagai salah satu penyebab kematian yang cukup besar di dunia. Berbagai penelitian telah membuktikan ada banyak bahaya merokok bagi kesehatan. Di antaranya yaitu asma, infeksi paru-paru, kanker mulut, kanker tenggorokan, kanker paru-paru, serangan jantung, stroke, demensia, disfungsi ereksi (impoten), dan sebagainya. Rokok mengandung zat-zat berbahaya, seperti tar, nikotin, karbon monoksida, dan bahan kimia berbahaya lainnya. Asap rokok mengandung 4.000 partikel zat kimia, 200 di antaranya mengandung racun dan 43 jenis lainnya bersifat karsinogen. ${ }^{(1)}$

WHO menyebutkan diamerika serikat 346.000 orang meninggal setiap tahun karena penyakit yang disebabkan oleh rokok dan $89 \%$ kematian akibat kanker paru-paru di Inggris diakibatkan oleh rokok. Sedangkan Indonesia merupakan urutan ketiga dalam hal perokok setelah China dan India. Saat ini jumlah perokok di Indonesia sekitar 60 juta orang. Menurut data Kementerian Kesehatan, hampir 2 juta anak Indonesia berusia 7-18 tahun merokok rata-rata dua batang setiap hari.
Menurut data Organisasi Kesehatan Dunia (WHO), 50 juta orang meninggal dunia akibat rokok pada tahun 2000. Sekitar 50 persennya terjadi di negara berkembang. ${ }^{(1)}$

Bahaya merokok bagi kesehatan ini tidak hanya berlaku bagi perokok saja. Pasalnya, orang-orang yang ada di sekitar perokok pun berisiko tinggi terkena efek rokok tersebut, meskipun mereka sendiri tidak merokok. $^{(2)}$

Beberapa tahun belakangan bahaya tentang asap rokok tidak hanya difokuskan kepada perokok aktif saja namun juga dampak yang diterima oleh perokok pasif. Semakin meningkatnya masalah yang diterima oleh perokok pasif baik di rumah maupun di lingkungan tempat kerja memungkinkan terjadinya dampak yang ditimbulkan oleh asap rokok. Hal tersebut menunjukkan terdapatnya bahaya ganda yang ditimbulkan oleh asap rokok yang tidak hanya diterima oleh perokok aktif namun juga oleh orang di sekitarnya ${ }^{(3)}$

Perokok pasif adalah seseorang yang dipaksa untuk menghirup asap rokok. Sedangkan yang dimaksud dengan merokok pasif, adalah paparan asap rokok yang diterima oleh non perokok yang terdiri dari campuran 
hembusan asap perokok aktif dan asap dari rokok yang dibakar atau dengan menggunakan alat merokok lainnya seperti pipa, bidi, cerutu dan lain sebagainya yang larut dalam udara ambien $^{(4)}$

Satu batang rokok mengandung lebih dari 250 bahan kimia aktif karsinogenik (penyebab kanker), termasuk formaldehida, benzena, vinil klorida, arsenik, amonia, dan hidrogen sianida. Asap buangan rokok mengandung karbon monoksida lima kali lipat, tar dan nikotin tiga kali lipat, dan amonia hingga 46 kali lipat lebih banyak daripada asap yang dihirup langsung oleh perokok aktif. Artinya, peluang kanker bagi para perokok pasif bisa mencapai hingga 50 kali lipat lebih tinggi dibandingkan dengan yang merokok.

Pertimbangan pemerintah dalam melindungi anak terhadap dampak tembakau yaitu rokok beserta zat adiktif yang dikandungnya merupakan landasan bagi Pemerintah Indonesia untuk mengendalikan masalah rokok. Undang-undang nomor 23/2002 tentang Perlindungan Anak, pasal 59 dan 67 menyatakan secara tegas bahwa pemerintah dan lembaga negara lainnya wajib bertanggung jawab memberikan perlindungan khusus kepada anak dalam situasi darurat, dimana salah satunya adalah anak yang menjadi korban penyalahgunaan zat adiktif, termasuk rokok. ${ }^{(5)}$

Selain itu, sistem kekebalan tubuh anak-anak juga belum terbentuk sempurna sehingga mereka lebih mudah terkena radang pernapasan, seperti bronkitis dan pneumonia. Bayi yang sering terpapar oleh asap rokok dalam jangka waktu panjang, atau yang ibunya merupakan perokok aktif, memiliki peluang yang lebih tinggi terhadap risiko kematian akibat Sudden Infant Death Syndrome (SIDS) daripada bayi yang tidak terpapar oleh asap rokok. ${ }^{(6)}$

Data yang dilaporkan UNICEF 2012 menunjukkan bahwa pneumonia sebagai hasil dari Infeksi Saluran Pernapasan Akut (ISPA) akibat menghirup asap rokok sekunder menempati peringkat tertinggi kematian anak Indonesia, tercatat sebesar $14 \%$ atau sekitar 21 ribu anak, melebihi angka kematian akibat AIDS, malaria, dan TBC. ${ }^{(6)}$

Di Kabupaten Kendal prosentase perokok di dominasi oleh pria, dimana hampir 85\% menjadi perokok aktif. Sedangkan pola 10 penyakit terbanyak pada pasien yang ada di puskesmas berdasarkan laporan SP3 Puskesmas menunjukan bahwa kasus infeksi saluran pernapasan atas (ISPA) masih menajdi kasus terbanyak di Kabupaten Kendal sebesar 140.305 penderita. Sedangkan kasus spesifik TB paru pada tahun 2016 sebesar 48,86 per
100.000 penduduk. Pada kasus pneumonia balita di kabupaten kendal untuk tahun 2016 mengalami tren peningkatan yang cukup signifikan dibandingkan pada tahun 2015, naik menjadi 134,39\% pada tahun 2016 dari $49,21 \%$ pada tahun $2015 .{ }^{(7)}$

\section{Pengertian Rokok}

Rokok adalah salah satu zat adiktif yang bila digunakan mengakibatkan bahaya bagi kesehatan individu dan masyarakat. Kemudian ada juga yang menyebutkan bahwa rokok adalah hasil olahan tembakau terbungkus termasuk cerutu atau bahan lainya yang dihasilkan dari tanamam Nicotiana Tabacum, Nicotiana Rustica dan spesies lainnya atau sintesisnya yang mengandung nikotin dan tar dengan atau tanpa bahan tambahan ${ }^{(8)}$

\section{Bahan-Bahan Kimia Yang Terkandung Dalam Rokok}

1. Tar

Tar adalah zat berwarna coklat berisi berbagai jenis hidrokarbon aromatik polisiklik, amin aromatik dan N-nitrosamine. Tar yang dihasilkan asap rokok akan menimbulkan iritasi pada saluran napas, menyebabkan bronchitis, kanker nasofaring dan kanker paru. ${ }^{(8)}$

2. Nikotin

Nikotin adalah zat atau bahan senyawa pirolidin yang terdapat dalam Nicotiana tobacum, Nicotiana rustica dan spesies lainnya atau sintesisnya yang bersifat adiktif saraf sehingga dapat mengakibatkan meracuni saraf tubuh, meningkatkan tekanan darah, menimbulkan penyempitan pembuluh darah tepi, dan menyebabkan ketagihan dan ketergantungan pada pemakainya (PP RI No. 19 Tahun 2003). Nikotin yang terkandung dalam rokok adalah sebesar 0,5-3 nanogram, dan semuanya diserap sehingga didalam cairan darah ada sekitar 40-50 nanogram nikotin setiap 1 mlnya. Nikotin yang dikandung rokok melepaskan hormon yang mengaktifkan beberapa reseptor di otak. Penggunaan nikotin mengakibatkan konsentrasi yang meningkat dan ketahanan tubuh untuk tidak lelah lebih lama . Selain itu, nikotin juga memiliki efek adiktif dan psikoaktif. ${ }^{(9)}$

3. Karbon monoksida

Karbon monoksida (CO) adalah gas beracun yang mempunyai afinitas kuat terhadap hemoglobin pada sel darah merah, ikatan $\mathrm{CO}$ dengan haemoglobin akan membuat haemoglobin tidak bisa melepaskan ikatan $\mathrm{CO}$ dan sebagai akibatnya fungsi haemoglobin sebagai pengangkut oksigen berkurang, sehingga membentuk karboksi hemoglobin mencapai tingkat tertentu akan dapat menyebabkan kematian. ${ }^{(8)}$

4. Timah hitam

Timah hitam $(\mathrm{Pb})$ yang dihasilkan oleh sebatang rokok sebanyak 0,5 ug. Sebungkus 
rokok (isi 20 batang) yang habis dihisap dalam satu hari akan menghasilkan 10 ug. Sementara ambang batas bahaya timah hitam yang masuk ke dalam tubuh adalah 20 ug per hari. Bisa dibayangkan, bila seorang perokok berat menghisap rata-rata 2 bungkus rokok per hari, berapa banyak zat berbahaya ini masuk ke dalam tubuh ${ }^{(8)}$

\section{Kategori perokok}

1. Perokok pasif

Perokok pasif dalam asap rokok yang dihirup oleh seseorang yang tidak merokok (Pasive smoker). Asap rokok merupakan polutan bagi manusia dan lingkungan sekitarnya. Asap rokok lebih berbahaya terhadap perokok pasif dari pada perokok aktif. Asap rokok sigaret berkemungkinan besar berbahaya terhadap mereka yang bukan perokok, terutama ditempat tertutup. Asap rokok yang dihembuskan oleh perokok aktif dan terhirup oleh perokok pasif, lima kali lebih banyak mengandung karbon monoksida, empat kali lebih banyak mengandung tar dan nikotin. ${ }^{(10)}$

2. Perokok aktif

Perokok aktif adalah asap rokok yang berasal dari isapan perokok atau asap utama pada rokok yang dihisap (mainstream). Dari pendapat diatas dapat ditarik kesimpulan bahwa perokok aktif adalah orang yang merokok dan langsung menghisap rokok serta bisa mengakibatkan bahaya bagi kesehatan diri sendiri maupun lingkungan sekitar. ${ }^{(3)}$

\section{Jumlah Rokok Yang Dihisap}

Jumlah rokok yang dihisap dapat dalam satu batang, bungkus, pak per hari. Jenis rokok dapat dibagi atas 3 kelompok yaitu ${ }^{(3)}$ :

1. Perokok Ringan yaitu apabila merokok kurang dari 10 batang perhari.

2. Perokok sedang yaitu apabila merokok 10-20 batang perhari.

3. Perokok Berat yaitu apabila merokok lebih dari 20 batang

Bila sebatang rokok dihabiskan dalam 10x hisapan asap rokok maka dalam tempo setahun bagi perokok sejumlah 20 batang (satu bungkus) per hari akan mengalami 70.000 hisapan asap rokok. Beberapa zat kimia dalam rokok yang berbahaya bagi kesehatan bersifat kumulatif (ditimbun), suatu saat dosis racunnya akan mencapai titik toksis sehinggga akan mulai kelihatan gejala yang yang ditimbulkan. ${ }^{(11)}$

\section{Bahaya merokok}

Bahaya merokok menurut (Depkes RI dalam Poltekkes Depkes, 2010) adalah:

1. Bagi perokok aktif

a. Meningkatkan risiko dua kali lebih besar untuk mengalami serangan jantung. Merokok dapat meningkatkan tekana darah dan mempercepat denyut jantung sehingga pemasokan zat asam kurang dan keadaan ini memberatkan tugas otot jantung. Merokok dapat mempertebal dinding pembuluh darah yang berakibat jantung kesulitan dalam memompa darah $^{(12)}$.

b. Meningkatkan risiko dua kali lebih besar untuk mengalami stroke

c. Meningkatkan risiko mengalami serangan jantung dua kali lebih besar pada mereka yang mengalami tekanan darah tinggi atau kadar kolesterol tinggi

d. Meningkatkan risiko sepuluh kali lebih besar untuk mengalami serangan jantung bagi wanita pengguna pil KB

e. Meningkatkan risiko lima kali lebih besar menderita kerusakan jaringan anggota tubuh yang rentan. Zat dalam rokok yang bersifat karsinogenik adalah tar, dapat meyebabkan kanker paru-paru karena sebagian besar zat ini tersimpan didalam paru-paru. Selain itu, tar ini dapat menyebakan kanker jika merangsang tubuh dalam waktu yang lama, biasanya didaerah mulut dan tenggorokan $^{(12)}$.

2. Bagi perokok pasif

Asap sampingan (sidestream smoke) hasil dari ujung rokok yang terbakar ternyata lebih berbahaya dibandingkan asap utama (mainstream smoke) yang dihisap dan dikeluarkan oleh perokok, karena mengandung 2 kali lebih banyak nikotin, 3 kali kandungan tar dan kandungan karbon monoksida 5 kali lebih banyak. Perokok pasif yang berada disekitar perokok aktif akan menghirup dua jenis rokok ini sekaligus, sehingga mengalami risiko gangguan kesehatan seperti mata perih, bersin dan batuk-batuk, sakit kerongkongan, sakit kepala, hingga masalah pernapasan termasuk radang paru-paru dan bronkitis, dan meningkatkan risiko kanker paru dan penyakit jantung $\left({ }^{13)}\right.$.

Merokok sangat berhubungan dengan penyakit jantung, pernapasan, kanker dan risiko penyakit lainnya. Pembuluh darah pada orang yang merokok terjadi penyempitan sehingga tekanan darah meningkat. Hal ini dapat menyebabkan stroke apabila menyumbat pembuluh darah di otak atau vena sekitar otak. Penyakit paru-paru seperti PPOK, emphysema, chronic bronchitis dan asma merupakan dampak dari merokok yang merusak saluran pernapasan dan alveolus. Perokok akan mengalami bronkitis dengan gejala awal batuk yang berkepanjangan, karena paru-paru tidak dapat melepaskan mukus yng terdapat dalam bronkus secara normal. Hal ini disebabkan karena asap rokok dapat memperlambat pergerakan silia dan setelah jangka waktu lama akan rusak sehingga perokok lebih sering batuk ${ }^{(12)}$ 
Wanita yang sedang mengandung sangat berisiko terjadi gangguan pada kehamilannya, dapat menyebabkan kematian bayi dalam kandungan, BB bayi rendah, kelahiran imatur, kehamilan ektopik (hamil diluar rahim), dan cacat dibagian wajah. Sperma pada perokok jumlahnya lebih sedikit, disfungsi ereksi dan kualitas sperma buruk, karena bahan kimia yang terkandung dalam rokok dapat masuk kedalam aliran darah yang secara langsung mempengaruhi sperma ${ }^{(3)}$ Dampak rokok dapat mempengaruhi penampilan seperti keriput pada wajah, kecerahan kulit yang buruk, kulit kendor dan rambut rontok. Hal ini disebabkan asap rokok yang merusak kolagen, elastin dan kekuranngan oksigen pada kulit. Penyakit lain yang disebabkan dari perokok yaitu katarak, diabetes mellitus tipe 2, artritis reumatoid (peradangan sendi) $^{(8)}$

\section{Metode Penelitian}

Penelitian ini termasuk penelitian kualitatif dengan pendekatan studi fenomenologi. Subyek dalam penelitian ini adalah perokok aktif yang ada di RW IV RT 10 Kelurahan Pegulon yang di keluarganya memiliki anak balita dan bertempat tinggal yang sama sebanyak 5 sebagai informan utama. Data yang diambil dalam penelitian ini adalah data primer melalui wawancara mendalam. Setelah pengumpulan selesai dilaksanakan maka data daianalisis menggunakan metode analisis isi (conten analysis), Analisis ini merupakan suatu tehnik untuk mengambilkan kesimpulan dengan mengidentifikasi karakteristik khusus atau pesan obyektif dan sistematis atau suatu tehnik penelitian untuk membuat inferensiinferensi dengan mengidentifikasi secara sistemik dan obyektif karakteristik khusus dalam sebuah teks dengan tahapan pengumpulan data, reduksi data, penyajian data dan menarik kesimpulan.

\section{Hasil dan Pembahasan}

\section{a. Persepsi perokok aktif tentang} kebiasaan merokok

Merokok merupakan kebiasaaan buruk di masyarakat yang sudah dianggap menjadi biasa, karena banyaknya para perokok atau juga karena begitu banyaknya aktivitas merokok yang biasa dijumpai disekitar kita sehingga merokok menjadi hal yang lumrah dan biasa saja. Hasil wawancara pada informan utama di peroleh bahwa seluruh informan menyatakan kebiasaan merokok sudah cukup lama lebih dari 15 tahun. Jumlah rokok yang dikonsumsi sehari adalah 7 batang sampai dengan 12 batang.
" saya merokok dari remaja sampai sekarang kira-kira sudah 20 tahun. Gak tau kenapa ya..pekerjaan saya di lapangan juga menuntut saya untuk merokok..paling banyak ya 1 bungkus sehari. Kayak nyaman aja gitu kalo ngrokok. (R-1)

"ngrokok ya tidak sehat sebenernya, tapi mau berhenti kok gak bisa ya..sehari paling tidak harus merokok 7-10 batang, biar fress. Apalagi kalo lagi pusing..ya pasti ngrokok. Saya udah lama merokok dari SMP ya kira-kira sudah 25 tahun.(R2)

"sudah lama sekali saya merokok, wong dari umur belasan tahun. Dulunya ya karna ikut-ikutan eh..keterusan. sehari ya paling tidak 10 batang " (R-3)

"udah lama..sekitar 15 tahunanlah..sehari bisa sampai 2 bungkus. Tapi alhamdulilah gak apa-apa..sehat-sehat saja” (R-4)

“ merokok ya bisa sampai 10 batang lebih, udah kebiasaan jadi susah berhentinya wong dari saya umur 17 tahunanlah.

Alasan merokok untuk menghilangkan pusing dan stres tidak dapat dipungkiri, karena nikotin yang terdapat dalam rokok dapat membawa ketenangan. Dengan demikian pusing atau stres pun akan hilang. Padahal semakin lama merokok, semakin sulit untuk menghentikannya dan semakin memperparak kerusakan organ tubuh perokok.

Nikotin memproduksi perasaan senang yang membuat para perokok ingin terusterusan merokok. Setelah sistem saraf beradaptasi dengan nikotin, perokok cenderung menambah jumlah batang rokok yang dihisap. Akibatnya kadar nikotin dalam darah juga meningkat. Dosis 30-60 mg dari nikotin dianggap sebagai dosis yang paling mematikan pada manusia. Nikotin adalah salah satu racun yang bekerja sangat cepat. ${ }^{(14)}$

Efek ketagihan dari nikotin berasal dari fungsinya dalam merangsang pembentukan dopamine senyawa kimia dalam otak yang menimbulkan perasan senang. Penelitian terkini menunjukan bahwa pengakain nikotin dalam waktu lama akan menurunkan kemampuan otak untuk mengenali perasaan senang yang sesuangguhnya. Oleh karena itu, para 
perokok biasanyan menambah batang rokok yang disulut setiap harinya untuk memperoleh kenikmatan yang sma seperti saat pertama kali merokok. ${ }^{(11)}$

Saat seorang perokok berusaha mengurangi atau menghentikan kebiasaan merokok ketiadaan nikotin bisa menimbulkan efek ketagihan. Efek ketagihan ini bisa muncul dalam dua sisi yakni mental dan fisik. Gejala ketagihan yang muncul dapat berupa pusing, depresi, merasa frustasi dan mudah marah., sulit tidur dan peralelah dan peningkatan napsu makan. ${ }^{(11)}$

b. Persepsi perokok aktif tentang dampak merokok bagi perokok aktif

Di Indonesia, jumlah kematian akibat penyakit yang disebabkan dari kebiasaan merokok mencapai 300 ribu pertahun. Hampir 60 persen kematian di Indonesia disebabkan oleh penyakit tidak menular (PTM) yang disebabkan oleh rokok seperti stroke,hipertensi dan penyakit jantung yang kini jumlahnya semakin meningkat. Dari hasil wawancara mendalam pada semua informan utama menyatakan bahwa 3 informan hanya menyebutkan bahwa dampak rokok adalah penyakit paru-paru seperti batuk dan sesak nafas. Sedangkan 2 informan menyebutkan bahwa dampak rokok seperti pada iklan rokok yaitu dapat mengganggu kesehatan tubuh terutama paru-paru, hipertensi, impotensi dan gangguan kehamilan serta dapat keguguran pada ibu hamil yang merokok.

" ya yang saya tau klo merokok itu akan berdampak pada kesehatan tubuh seperti penyakit kanker paru-paru dan bisa juga sesak nafas" (R-1)

"katanya sih merokok itu dapat menyebabkan penyakit paru-paru, hiperteni, impotensi dan gangguan kehamilan dan janin “ (R-2)

" klo merokok ya bisa terkena penyakit paru-paru, kalau paru-paru bermasalah kan bisa jadi batuk-batuk, sesak nafas dan meninggal" (R-3)

"kalo kata iklan rokok itu ya merokok dapat mempengaruhi kesehatan jantung, paru-paru terus bisa kena kanker tenggorokan" (R-4)

" merokok dapat membunuhmu karena kalo merokok itu akan mempengaruhi kesehatannya terutapa di organ pernapasan. Jadi berbahaya “ (R-5)

Nikotin merupakan zat yang dapat membuat seorang perokok kecanduan.
Pada awalnya, perokok aktif ini akan merasakan nikmatnya menghisap asap rokok. Bagi mereka yang merokok mengatakan bahwa rokok membuat tubuh terasa segar, meningkatkan gairah dan semangat. Hal itu memang ada sebenarnya karena nikotin didalam rokok dapat menstimulasi kerja jantung lebih cepat. Akibatnya, peredaran darah mengalir lebih cepat pula. ${ }^{(14)}$

Ditubuh, nikotin dalam dosis rendah berdampak pada gangguan saluran pernapasan. Namun, nikotin dengan kadar banyak akan menyumbat peredaran darah. Akibatnya, perokok mengalami berbagai penyakit, seperti serangan jantung dan stoke. Bahkan merokok menimbulkan kanker, impotensi dan gangguan kehamilan. Tidak hanya nikotin, didalam rokok juga mengandung berbagai jenis racun lain yang berdampak pada kesehatan. Bahan-bahan ini akan menghambat proses regenerasi sel-sel di tubuh. Tar di rokok menyebabkan gigi berubah kuning kecoklatan. Dampak lain, kulit menjadi cepat keriput dan kusam. ${ }^{(14)}$ Saat menghirup asap rokok, nikotin turut masuk ke paru-paru, kemudian diabsorbsi sangat cepat kedalam aliran darah dan menyebar keseluruh tubuh. Nikotin mempengaruhi banyak organ, termasuk jantung dan pembuluh darah, sistem hormon, metabolisme dan otak. Nikotin juga ditemukan pada air susu ibu yang merokok, bahkan pada lendir hasil sekresi serviks. Selama kehamilan, nikotin dapat dengan bebas berkeliaran di plasenta, air ketuban (amniotic fluid) dan tali pusat janin. $^{(11)}$

\section{c. Perilaku kebiasaan merokok di} lingkungan umum

Dari hasil wawancara bahwa semua responden menyatakan bahwa saat merokok ditempat umum dipengaruhi juga perilaku merokok dari kumpulannya.

"kalau teman-teman lain pada kumpul
dan merokok, ya saya ikutan.. walaupun
itu ditempat umum, kalau dirumah ya
kadang-kadang ngerokok di dalam
rumah yang penting gak didekat anak-
anak" (R-1)
"gak pilih-pilih tempat sih, kalau pingin
ngrokok ya ngrokok aja dimanapun" (R-
2) "kadang saya liat-lihat dulu, kalau disitu
ada anak kecil saya mencari tempat
untuk merokok yang jauh dari anak
kecil" (R-3)
dan merokok, ya saya ikutan..walaupun mah ya diakanak" (R-1)

" gak pilih-pilih tempat sih, kalau pingin ngrokok ya ngrokok aja dimanapun” (R2) untuk merokok yang jauh dari anak kecil" (R-3) 
" lihat-lihat juga ngerokoknya, kalau disitu rame dan tidak ada yang merokok ya saya merokoknya agak jauh, kaya contohnya kalau kumpulan warga, disitu pada merokok ya saya ikutan merokok" (R-4)

“ saat nyetir mobil malam, kadang saya buka kaca jendel mobil biar asapnya tidak masuk ke mobil dan kena istri dan anak-anak. (R-5)

Merokok akan mempengaruhi lingkungan, orang lain, atau orang terdekat. Seorang yang bukan perokok bila terus-menerus terkena asap rokok dapat menerima dampak yang sama dengan perokok. Merokok juga dapat mengakibatkan napas berbau, warna kecokelatan pada kuku dan gigi, serta bau yang tidak enak pada rambut dan pakaian, disamping itu kulit menjadi lebih keriput lebih awal. ${ }^{(15)}$

Asap rokok juga mengakibatkan ruangan menjadi berbau kurang enak. Tar yang terkandung diasap rokok akan menempel di dinding. Akibatnya, perokok pasifpun mengalami warna cat tembok cenderung berwarna kecoklatan. Ruangan yang sering kali di pakai untuk merokok tampak lebih kusam dibanding yang tidak digunakan merokok. ${ }^{(1)}$

Asap rokok juga menyumbang peningkatan pencemaran udara. Kebiasaan orang-orang merokok yang leluasa merokok di tempat umum seperti halte, kendaraan umum, tempat hiburan, stasiun, terminal, pasar dan fasilitas umum. Untuk itu dukungan pemerintah dengan membuat ruangan khusus merokok dapat menghindari perokok pasif dari asap rokok dari perokok aktif. ${ }^{(1)}$

\section{d. Persepsi perokok aktif tentang dampak} asap rokok bagi perokok pasif

Asap rokok telah dipastikan sebagai penyebab kanker pada manusia. Asap rokok yang dihirup perokok pasif adalah penyebab utama kanker paru-paru pada orang-orang yang bukan perokok. Risiko kanker paru meningkat hingga 20-30\% pada orang-orang yang tidak merokok tapi selalu dikelilingi oleh asap rokok, dibanding non-perokok yang tidak terkena paparan asap.

Selain kanker, perokok pasif juga sama berisikonya untuk terkena penyakit jantung seperti perokok aktif. Meski tidak pernah merokok sebelumnya, perokok pasif bisa mengalami peningkatan risiko penyakit jantung hingga sekitar 25-30\% dibanding dengan non-perokok yang tidak pernah terkena paparan asap rokok.

“"katanya dampaknya lebih bahaya dari
yang merokok, tapi kurang tau
bahayanya seperti apa “( (R-1)
" ya ada dampaknya, kaya batuk-batuk
karena asapnya" (R-2)
" ya bisa mempengaruhi juga saluran
pernapasannya, kalau sering terpapar bisa
mempengaruhi kesehatannya seperti kena
kanker juga bisa” (R-3)
"bisa sesak nafas juga karena sering
menghirup asap rokok, apalagi anak-
anak" (R-4)
"tidak faham benar dengan dampaknya
(R-5)

Perokok pasif yang tinggal di lingkungan perokok aktif akan memiliki kandungan nikotin dalam darah dalam jumlah yang sama dengan perokok kelas menengah (orang yang merokok sekitar 10 batang sehari $)^{(1)}$

Selain menyebabkan berbagai gangguan kesehatan, rokok dapat berakibat buruk pada orang lain yang ada disekitarnya. Orang- orang ini disebut perokok pasif. Mereka terpaksa menghirup asap rokok dari perokok aktif. Akibatnya, prokok pasif pun mengalami gangguan yang sama dengan prokok aktif. ${ }^{(14)}$

Tanpa disadari, perokok pasif telah menghirup bahan-bahan kimia berbahaya yang berasal dari asap rokok. Meskipun kadar bahan-bahan kimiayang masuk ke udara tersebut belum melebihi ambang batasyang diperolehkan, jika terjadi apapran dalam waktu yang lama dan terusmenerus dapat berpengaruh bagi keseahtan. ${ }^{(16)}$

Kurangnya kesadaran dan sikap negatif masyarakat tentang bahaya rokok bagi diri dan orang-orang di sekelilingnya menyebabkan kurangnya kemampuan masyarakat untuk merubah perilakunya dan menciptakan lingkungan yang sehat.Untuk itu perlu dilakukan upaya pencegahan baik di lingkungan rumah, sekolah, maupun lingkungan masyarakat. Salah satu upaya pencegahan yang dapat dilakukan adalah kegiatan penyuluhan dan bimbingan untuk memberikan penerangan dan pengetahuan kepada sasaran yang menyalahgunakan dan untuk membangkitkan kesadaran mereka tentang rokok. ${ }^{(15)}$

\section{Kesimpulan}


Kesimpulan yang dapat ditarik adalah sebagian besar informan menunjukkan bahwa informan utama sudah mengerti tentang bahaya asap rokok bagi perokok aktif, namun tidak memahami tentang bahaya merokok bagi perokok pasif sehingga kesadaran untuk merokok di tempat yang jauh dari jangkauan anak balita belum ada.

\section{Daftar Pustaka}

[1] Sugito, J. Stop Rokok, Mudah Murah Cepat. Redaksi Plus Penebar Swadaya, Depok. 2007

[2] Swari

Rizky.

2017.

(https://hellosehat.com/hidup-

sehat/berhenti-merokok/bahaya-merokokpada-daya-tahan-tubuh/). Diakses tanggal 10 Juli 2019

[3] Bustan, M. Epidemiologi Penyakit Tidak Menular. Jakarta: Rineka Cipta. 2007

[4] World Health Organization, 2013. World Health Statistic 2013. New York: WHO Publication.

[5] Depkes RI, 2012. (http://www.depkes.go.id/article/print/2051/ pemerintah-terus-berupaya-kendalikandampak-merokok.html) diakses tanggal 10 Juli 2019

[6] Quamila, Ajeng. 2017.( https://hellosehat.com/hidup-sehat/berhentimerokok/bahaya-asap-rokok-bagi-perokokpasif/merokok-dekat-anak-adalahpenganiayaan-anak) diakses tanggal 25 Juli 2019.

[7] Dinkes Kabupaten. Profil Kesehatan Kabupaten Kendal, 2016

[8] Triswanto, S. Stop Smoking. Sleman : Progresif book. 2007.

[9] Nainggilan, R, A. Anda Mau Berhenti Merokok? Pasti Bisa. Bandung: Indonesia Publishing House. 2006.

[10] Wardoyo. Pencegahan Panyakit Jantung koroner. Solo: Toko Buku Agency. 1996.

[11] Sitepoe M. Kekhususan Rokok Indonesia. Jakarata: Grasindo. 2000.

[12] Nururrahmah,2014 Nururrahmah. 2014.’Pengaruh Rokok Terhadap Kesehatan Dan Pembentukan Karakter Manusia". Seminar, Vol 01, Nomor 1. Universitas Cokroaminoto. Palopo. Hal 78 - 84.

[13] Novarianto J. Hubungan Persepsi Remaja tentang Peringatan Kesehatan Bergambar pada Kemasan Rokok dengan Motivasi Berhenti Merokok pada Remaja di
Madrasah Aliyah Al-Qodiri Kecamatan Patrang Kabupaten Jember. Jember: Universitas Jember. 2015

[14] Sukmana, Tedie. Mengenal Rokok Dan Bahayanya. Be Champion, Jakarta. 2017

[15] Kemenkes RI. 2013. Hasil Riskesdas 2013.(http://depkes.go.id/downloads/riskesd as2013/ Hasil\%20Riskesdas\%202013.pdf.)

[16] Anna. Bahaya Nyata dari Rokok, Kompas.com. (https://lifestyle.kompas.com/read/2010/05/ 31/11004732/bahaya.nyata.dari.rokok) diakses tanggal 10 Juli 2019 